VALENTINa ChKHEIDZE

Akaki Tsereteli State University

DOI: $10.13166 / J M S / 113394$

Kutaisi, Georgia

valenta-val@mail.ru

ORCID: 0000-0003-0197-8169

ZINAIDA CHACHANIDZE

Akaki Tsereteli State University

Kutaisi, Georgia

chachanidzeziniko@gmail.com

ORCID: 0000-0002-1733-6104

\title{
Niko Gomelauri's POETRY AS A GUIDE OF INTERCULTURAL COMMUNICATION
}

\begin{abstract}
Poetic multilingualism as a variety of polylingualism, in general, is a good material for studying cultural transfers (the process of transferring knowledge between different cultures, professional communities and discourses) from both linguistic and culturological point of views. The creative work of bilingual poets, whose phenomenon has not been studied yet, is one of the guides of intercultural communication. Among such poets, Niko Gomelauri has a prominent place, who made a great contribution to both Georgian and Russian literature, nonetheless, neither Georgian nor Russian philologists study the materials based on his works.

Research aims. To draw researchers' attention to the creative works of a bilingual poet Niko Gomelauri, we present the linguistic analysis of Niko Gomelauri's five different poems belonging to different genres, define peculiarities of his poetic works and stylistic tendencies.

Research methods. Through using semantic and stylistic, descriptive and comparative methods and the analysis of dictionary articles we have thoroughly analysed Gomelauri's poetic words.

Conclusions. Linguistic anaysis of poems of different genres revealed Niko Gomelauri's peculiar vision. A bilingual poet has a wider world vision, sees deeper and gives his poetic worlds a more philosophical idea or emotional content. The analysis of Gomelauri's poems showed two stylistic tendencies in his poetry - deeply philosophical and mockery-colloquial.
\end{abstract}


KEYwORDs: intercultural communication, bilingual-poet, expressive means, metaphor, comparison

\section{INTRODUCTION}

In the poly-lingual space of the XXI century, the issues of intercultural, scientific cooperation and international communication are of particular significance. This is proved by both scientific research discussed at numerous scientific-practical conferences dedicated to these issues and individual relationships in diplomacy, politics, economics, culture, business, sport, tourism, as well as on an everyday basis. Bilinguals play a very important role in this respect, these are scientists, translators, experts in certain fields and ordinary people who live outside their country but are fluent in the language of the country of their residence; intercultural communication becomes an everyday event and in the process of intercultural communication people acquire not only the knowledge of foreign languages but also the knowledge of material and spiritual culture and world vision of another country.

The issue of bilingualism in a number of social sciences, includinglinguistics, is not new in human communication. A serious interest in bilingualism as a phenomenon of complex nature appeared quite a long time ago: the first attempts of its systematic study started in the XIX century (Nikolaev, 2006). However, among bilinguals, a special place is occupied by writers and poets who write in two languages as the specifics of their activity requires mastery of both languages - on an identical level and identical volume, without any of them being a dominant. This phenomenon has not been studied yet but is of great interest for a range of scientific disciplines, including linguistics. Though it is believed that enough has been written about bilingualism and multilingualism, especially in the Medieval poetry (Chelisheva, 2015, p. 183), that poetical multilingualism as a variety of polylingualism as a whole is a favourable material for the study of cultural transfers from both linguistic and culturological points of view (Feshenko, 2017, p. 17), the issue of poetic bilingualism is hardly studied in research literature. "Bilingualism is a phenomenon which is manifested by a number of its own variants and is quite far from adequate theoretical and linguistic realisation" (Nikolaev, 2006). At present, there is neither the theory of poetical bilingualism nor detailed 
and systematic historic observations according to which it will be possible to identify the main tendencies in the development of bilingualism in poetry.

Separate studies of the history of poetic bilingualism are mainly case studies of the development of European poetry, which mainly reflects upon separate issues of the formation of national literary languages (Azarova, 2016, p. 255).

Taking into consideration that the issues of bilingualism and polylingualism are still relevant in Georgia, in this multinational and tolerant country, due to historic and geopolitical being, there have always been a lot of people speaking two or three languages (Shalit, 2006; 2009; Chkheidze, 2016). The theme of political bilingualism is quite urgent for this country as well. In this aspect, the creative work of a bilingual poet Niko Gomelauri is of great interest. It has not been studied in either Georgian or Russian philology. The details and features of the short forms of his poetic texts have not been researched and the semantic load of every word of his poems has not been discussed yet.

Among small but valuable poetic heritage of Niko Gomelauri (he was only 39 when he died) - a gifted actor of theatre and cinema, and a gifted bilingual poet (he played and wrote in both Georgian and Russian languages), we have chosen five poems of different genres with different stylistic shades: "I will drink, drink the sea, smoke the mist..., "We will break through", "I is my second", "You are my good..., "No heart, no kidneys..." (Gomelauri, 2010; Gomelauri, 2011; Gomelauri, 2012).

Research aims. The article is the first attempt in philology to present a linguistic analysis of a bilingual poet Niko Gomelauri's several poems belonging to different genres, define stylistic tendencies of his poetical works based on these materials which reveal the difference between using stylistic and grammatical means as well as poetic devices.

Research methods. Taking into account the modern tendency, which is characterised by refusing a certain general method, we used a combination of different scientific, general and specific linguistic methods:

Semantic and stylistic method of learning sense nuisances of words in various contexts of Gomelauri's poetry;

Descriptive-contrastive method, which selects and describes the vocabulary of the poems of different genres; 
Inductive and deductive methods (on the one hand, gathering material and generalising the acquired information, on the other - making certain conclusions based on general statements);

The analysis of word articles (looking for relevant lexical and semantic data about analysed words and determining insufficiency of their understanding).

\section{PSYCHOLOGICAL AND CROSS-ASSOCIATIONS IN THE POEM "DRINK, DRINK THE SEA, SMOKE THE MIST..."}

After a superficial introduction to Niko Gomelauri's work, we may have the impression that he finds it easy to write poems, without much creative suffering and numerous corrections. This is quite understandable - shortage of time, lack of health and, most importantly, life. Nevertheless, behind every line, every word, every rhyme there is great labour, creative sufferings and search.

For example, in his poem "I will drink, drink the sea, smoke the mist...", there are numerous symbols and psychological associations:

Drink, drink sea, smoke the fog / I quarrel with everyone, I am friends with a volcano / I plunge into lava, I don't come up soon / I give up height and glory to mountains / And when I wash my bones in lava, / I will open everything for everyone, come to visit / I will spread the lines of fire for memory / Let us forget the squabbles, we will swim in happiness / The sun will be glad, the darkness will be in grief / But first you must ... you need to drink the sea [Gomelauri, 2011, p. 262].

The very first line of the poem introduces the reader with the world of mystery and secrets. It is impossible to "drink the sea", thus, the combination of these two words symbolises something unthinkable, which must be taken in great quantities (the sea - a great quantity, plenty of something, drink - swallow, partake liquid) [Dictionary of the Russian Language, vol. 4:270]. The word combination "smoke the fog" is more realistic as it is the image of a man in the mist, "soaked" by volcanic clouds. Nevertheless, the denotation of the word "fog" is combined with its connotation "vagueness, uncertainty, indefiniteness" [Dictionary of the Russian Language, vol. 4:425], and then we have an absolutely different image of the confused man looking for something, not being able to find anything. Having quarrelled with everyone, the 
character is "friends" with the volcano, submerges in its lava in order to wash "his bones". The phrase "am friends with" is used by the author figuratively which is marked as "colloquial" in some lexicographic editions - "be fond of something, be attracted to something" [Ozhegov, 1990:484]. We can only presume what is implied with the volcano, but it is something more, which gives up "height" and "glory" to others. And only when he emerges from lava, he will be given the opportunity to open doors and invite everybody and give away "lines of fire".

The word combination "lines of fire" is of great linguistic interest. Lines cannot be "fire". The adjective acquires a figurative sense of hot, passionate [Dictionary of the Russian Language, vol. 2:586], though we can see the main meaning connected with the noun "fire" - hot shining gases around a burning thing, flame [Dictionary of the Russian Language, vol. 2:587]. Besides, due to psychological associations with the volcano, there is a visual colour feature - the colour of fire, flame, bright red, orange-red [Dictionary of the Russian Language, vol. 2:585]. The second last line of the poem is also interesting: "The Sun will be glad, and the Darkness will be in grief". From the first sight, the nouns "Sun" and "Darkness" are personified objects, though Gomelauri, maybe subconsciously, gives "Sun" a figurative meaning of "something valuable, high, vital" [Ozhegov1990:744] and "Darkness" acquires an archaic sense of "ignorance, cultural retardness" [Dictionary of the Russian Language, vol. 4:434]. It is proved by analysing the contrastive and specific correlation with the previous line, which creates certain crossing associations, where happiness - "feeling and condition of high satisfaction with life, the feeling of deep joy" [Dictionary of the Russian Language, vol. 2:320] and squabble - is "an argument, hostile relationship because of minor intrigues, the struggle of private relations" [Dictionary of the Russian Language, vol. 2:110]:

squabble happiness

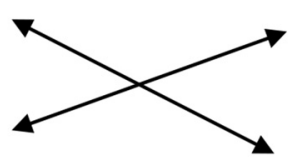

Sun

darkness 
Naturally, due to the above mentioned, the psychological processes are directed to the expectation of full victory of the Sun over Darkness, but the final, tenth line of the poem gives an unexpected turning

But first you must ... you need to drink the sea.

What is hidden behind the word "sea" is a mystery. One thing is clear - the character and, therefore, the author (although they are not identical, their images always have points of contact) are well familiar with the two powerful and incompatible natural elements - water and fire. For the full victory, it is necessary to do the impossible - being "friends" with the volcano, "drink the sea", which causes squall of new associations and related views from the actor and poet's life.

\section{TWO STYLISTIC TENDENCIES IN NIKO GOMELAURI'S POETRY}

The poem "Break through" is somehow similar to the previous one - the same philosophical depth of a small work, the same adjacent female rhyme with the stress on the second last syllable, the presence of the same inner rhyme, the same zigzag of the final line. In every second line, there are the words "break through", which is also the title of this small but powerful monologue-confession:

A friend abandoned me, and left for Heaven/Without giving up, I keep telling myself - we will break through / A brother abandoned me and looked at me with anger/But I am much stronger and say - we will break through/ the Spirit abandoned me, my nose is bleeding/But I say aloud that we will break through/Sleep abandoned me and insomnia is unbearable/I avoid grief and shout into darkness - we will break through/A son abandoned me, and then a daughter/I am sitting drunk alone, but wheeze - we will break through/But, mainly SHE left and told do not be afraid/Do not remember me and repeat - we will break through/But I wanted to fight with life together with her/And now, either sing or drink - where must I break through [Gomelauri, 2011, p. 260].

The phrase "break through" has several meanings, but only one of them is used in the first person - "force one's way forward" [Ozhegov, 1990:617]. 
Alongside the refrain, there is a chain of verbs with the common semantics "say, utter", which differ in degree of repetition, power or utterance ("tell myself", "say aloud", "repeat", "shout", "wheeze"). The sequence of these verbs shows the gradual growth of dynamics which reaches its apogee ("wheeze") and then drops sharply creating an unexpected zigzag. The noun "darkness" is used here in its primary rather than figurative meaning "lack of light" [Ozhegov, 1990:817].

The poem "I is my second..." is written in a slightly different style (Gomelauri, 2011, p. 225), a wonderful translation of which has been done by Elena Isaeva (Isaeva, 2010). Short phrases, scarcity of expressive means (only one comparison - "twists like a vulture", one phraseological unit - "calls for misfortune"), various syntax, presence of interrogative sentences, a number of homogeneous members help emphasise the complicated topic more vividly - a poet and a man in one guise, two images, two confrontations in one person. Who is main, who is more sincere - the ordinary or the creative?

The next poem is of a mocking character "You are my good..." (Gomelauri, 2010). Here is a small passage from it:

You are my good.../My little angel.../I will leave everything behind for you!/You are a piece of my heart.../Here is love! Here is no deceit!/I see God's handwriting!/I hope it is a novel/ and not an outline...

This is a peculiar, quite a primitive style devoid of any complicated associations where naive, simple, open and frank tone prevails, the tone usually used in conversation with friends and close people. The author uses a lot of comparisons ("You set the meter of my life as an engine", "You are like a thimbleful of water in the desert", "You and I are like 'a' and 'b"'); there are a lot of diminutives. This creates a sincere monologue-appeal to the beloved and the readers feel being the poet's close friends.

And, last, the fifth - a short, eight-line but very emotional poem - "No heart, no kidneys ..." (Gomelauri, 2011, p. 92). 
Fatally ill, destined to die, but strong within, Niko Gomelauri writes these magic words to his wife - Nino Chodrishvili, which are veiled/ hidden in the Georgian text but are vividly revealed while translated into Russian:

No heart, no kidneys,/Lungs - but I still struggle,/I breathe out the truth/Bitter in taste./But looking into Nina's eyes,/I seem to see the light in the window - /Didn't Paganini play/On only one string? (Isaeva, 2010).

Metaphorical images give the notions which are expressed by neutral words more vivid colours, make us feel the pain but, at the same time, strength and true love. And we remember David Markish's words, a famous Israeli writer, poet and publisher that Niko Gomelauri underwent his short way of artists, whose life is located "between „,', sun and molding pot, where the mysterious gold of creativity is being melted" (Markish, 2001, p. 247).

The present analysis of Niko Gomelauri's several poems reveals the presence of two stylistic tendencies in his creative work and proves that necessity of further research of his literary heritage and through philological analysis within the framework of bilingual contrastivics of texts in Georgian and Russian language.

\section{Conclusions}

To sum up, we can conclude:

1. Like other writers and poets writing in two languages, Niko Gomelauri has a special place among bilinguals as the specifics of his activity requires perfect knowledge of both languages. Niko Gomelauri, a bilingual poet and an actor, undoubtedly, had a broader world vision, lived in a broader world, saw deeper and further than monolinguals, which leads to using certain literary and expressive means.

2. The analysis of Gomelauri's poems showed two stylistic tendencies in his poetry - deeply philosophical and mockery-colloquial, which reveals versatile stylistic shade, different syntactical forms and means of expression, presence/absence of inner rhyme. 
3. Gomelauri's poetry, both Georgian and Russian, requires serious philological research in terms of studying his poems in one language as well as in comparison and in translation.

\section{References}

Azarova, N. (2015). Predisloviye ko vtoromu razdelu [Preface to the second section]. In: Kritika i semiotika [Criticism and semiotics]. ISSN 2307-1737 no 1. pp. 168-170. (in Russian).

Azarova, N. (2016). Poeticheskiy bilingvizm kak sredstvo mezhkulturnogo transfera [Poetic bilingualism as a means of intercultural transfer ]. In: Lingvistika i semiotika kul'turnykh transferov: metody, printsipy, tekhnologii : kollektivnaya monografiya./ Red. Feshchenko V.[Linguistics and semiotics of cultural transfers: methods, principles, technologies: a collective monograph / Ed. Feschenko V.] ISBN 9785902764762. Moskow: Kulturnaja revolucija, pp. 255-307. (in Russian).

Bagno,V. (2016) . Dar osobennyy: Khudozhestvennyy perevod v istorii russkoy kul'tury [A special gift: A literary translation in the history of Russian culture]. ISBN 9785444805909. Moscow: Novoye literaturnoye obozreniye, 360p. (in Russian).

Chelysheva, I. (2015). O nekotorykh aspektakh mnogoyazychiya v romanskoy srednevekovoy poezii [On some aspects of multilingualism in Romanesque medieval poetry]. In: Kritika i semiotika [Criticism and semiotics]. ISSN 2307-1737.no 1. pp. 182-190. (in Russian).

Chkheidze, V. (2016). Bilingvizm kak proyavleniye mezhkul'turnoy kommunikatsii [Bilingualism as a manifestation of intercultural communication]. In.: Russkoye kul'turnoye prostranstvo. Sbornik materialov XVII Mezhdunarodnoy nauchno-prakticheskoy konferentsii [Russian cultural space. Proceedingsof the XVII International Scientific and Practical Conference]. Issue. 5. Moscow: Pero, pp.771-775. (in Russian).

Feshchenko, V. (2017). Poeticheskiy mul'tilingvizm na karte Yevropy: yazykovyye kontakty i kul'turnyye transfery [Poetic multilingualism on the map of Europe: language contacts and cultural transfers]. In: Slovo.ru: baltiyskiy aktsent [Slovo.ru: Baltic accent]. Vol.8, №4, pp. 16-30. [Electronic resource]: https://cyberleninka. $\mathrm{ru} /$ article/n/poeticheskiy-multilingvizm-na-karte-evropy-yazykovye-kontakty-ikulturnye-transfery (access date: 28.01.2019). (in Russian).

Gomelauri, N. (2012). Stikhi. [Gomelauri, N. (2012). Poems. [Electronic resource]: http://playcast.ru/communities/georgia/?act=news\&id=33578] (access date: 25 . 01.2019). (in Russian). 
Gomelauri, N. (2011). Otsnebebi mtsnebebivit irghvevian [Dreams are broken like commandments]. ISBN 9789941061738. Tbilisi: Favoriti stilshi, 306 p. (in Georgian).

Levin, YU. (1985). Russkiye perevodchiki XIX v. i razvitiye khudozhestvennogo perevoda [Russian translators of the XIX century. and the development of literary translation]. ISBN:160BN2-01072017/04 . Leningrad: Nauka, 297 p. (in Russian).

Markish, D. (2011). Mtcckunvare mzesa da sadnob ghumels shoris [Between the harsh sun and the hot oven]. In: Gomelauri, N. (2011). Otsnebebi mtsnebebivit irghvevian [D, preams are broken like commandments]. ISBN 9789941061738. Tbilisi: Favoriti stilshi, pp. 4-5. (in Georgian).

Morse, A. (2015). Doiche Bukh: some observations on multilingual poetry. In: Kritika i semiotika [Criticism and semiotics]. ISSN 2307-1737. № 1, pp. 350-363. (in English).

Nikolayev, S. (2006). Fenomenologiya bilingvizma $\mathrm{v}$ tvorchestve russkikh poetov [Phenomenology of bilingualism in the works of Russian poets]. Dissertatsiya na soiskaniye uchenoy stepeni doktora filologicheskikh nauk [Dissertation for the degree of Doctor of Philology] (10.02.19, 10.02.01). Rostov-na-Donu, $163 \mathrm{p}$. (in Russian).

Isaeva, E. (2010). Niko Gomelauri. S kem v adu okazhus'?.. Perevod s gruzinskogo. [[Niko Gomelauri. Who will I end up in hell? .. Translated from Georgian]. In: Khreshchatyk. Literary and art magazine. № 1. [Electronic resource]: http://magazines.russ.ru/kreschatik/2010/1/go24.html (accessl date: 01/26/2019). (in Russian).

Ozhegov, S. (1990). Slovar' russkogo yazyka / Red N. Shvedova [The Dictionaly of the Russian Language / Ed. N. Shvedova] ISBN 5200010888. Moscow: Russkiy yazyk, 921p. (in Russian).

Parizhskiy, S. (2015). Trekh"yazychnoye stikhotvoreniye Yyekhudy al-Kharizi (XIII v.) [Three-lingual poem by Yehuda al-Harisi (13th century)]. In: Kritika i semiotika [Criticism and semiotics]. ISSN 2307-1737. № 1. pp. 219-235. (in Russian).

Slovar' russkogo yazyka v 4 tt. / Red. Yevgen'yeva (1981)[ The Dictionary of the Russian Language in 4 vol.] / Ed. A. Evgenieva. Moskow: Russkiy yazyk. Vol.I, 696 p. (in Russian).

Slovar' russkogo yazyka v 4 tt. / Red. Yevgen'yeva (1981)[ The Dictionary of the Russian Language in 4 vol.] / Ed. A. Evgenieva. Moskow: Russkiy yazyk. Vol.II, 736 p. (in Russian). 
Slovar' russkogo yazyka v 4 tt. / Red. Yevgen'yeva (1981)[ The Dictionary of the Russian Language in 4 vol.] / Ed. A. Evgenieva. Moskow: Russkiy yazyk. Vol. III, 750 p. (in Russian).

Slovar' russkogo yazyka v 4 tt. / Red. Yevgen'yeva (1981)[ The Dictionary of the Russian Language in 4 vol.] / Ed. A. Evgenieva. Moskow: Russkiy yazyk. Vol.IV, 794 p. (in Russian).

Stikhotvoreniya Niko Gomelauri(2010) [Niko Gomelauri's Poems] [Electronic resource]: http://ekser.livejournal.com/139398.html (access date: 07.02.2019). (in Russian).

Shalit, SH. (2006). Neottorzhimyye ot Siona. O sem'ye Babalikashvili [Unbreakable from Zion. About the Babalikashvili family]. In: Al'manakh «Yevreyskaya starina», №10 (46). [Electronic resource]: http://berkovich-zametki.com/2006/Starina/Nomer10/Shalit1.htm (access date: 01/26/2019). (in Russian).

Shalit, SH. (2009). Etot molodoy chelovek - geniy [This young man is a genius]. In: Zametki po yevreyskoy istorii, №14 (117). [Electronic resource]: http://berkovich-zametki.com/2009/Zametki/Nomer14/Shalit1.php (access date: 01/26/2019). (in Russian). 
